\title{
Characterization and Catalytic Properties of Surface La-rich $\mathrm{LaFeO}_{3} \mathrm{Perovskite}$
}

\author{
Young-Gil Cho, Kyong-Hoon Choi, ${ }^{\dagger}$ Yong-Rok Kim, Jin-Seung Jung, ${ }^{\ddagger}$ and Sung-Han Lee

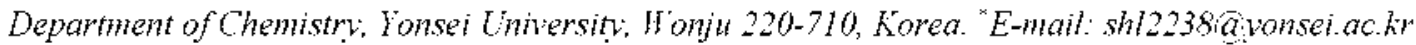 \\ †Deparment of Chemistry, Ionsei Lniversitv, Seoul 120-749, Korea \\ -Deparment of Chemistry, Kanghung National University. Gangning 210-320, Korea \\ Received December 8. 2008. Accepted January 8. 2009
}

Key Words: $\mathrm{LaFeO}_{3}$ perovskite. Total oxidation of methane. Oxidative coupling of methane

Perovskite-type $\mathrm{LaBO}_{3}(\mathrm{~B}=$ transition metal) oxides are proved to be highly active cataly sts for oxidation reactions in connection with air pollution control. Especially. they are considered as potential cataly'sts in substitution of noble metal catalysts because of their high thermostability. Many investigators have suggested that oxygen vacancies in the perovskite oxides play a major role in catalytic oxidations although there is still debate on the origin of their catalytic activity. ${ }^{1-7}$ In $\mathrm{LaBO}_{3}$ peovskite. oxygen vacancies can be generated by a partial substitution of the lanthanum ion or transition metal ion with an element of different valence. or by altering the $\mathrm{La} / \mathrm{B}$ ratio in the preparation. ${ }^{8}$ To obtain a homogeneous and single phase $\mathrm{LaBO}_{3}$ perovskite, the sol-gel method or the co-precipitation method is usually used. However a part of transition metal atoms in $\mathrm{LaBO}_{3}$ perovskite can exist in higher or lower oxidation states. which may induce the formation of anion or cation defects in the oxide. Accordingly. the surface composition may be different from the bulk one. which may significantly modify the catalytic properties of pure $\mathrm{LaBO}_{3}$ perovskite

$\mathrm{LaFeO}_{3}$ perovskite cataly'st is known to be highly active in total oxidation of methane. Its activity is generally explained by the fluctuation between two stable oxidation states of Fe. $\mathrm{Fe}^{--}$and $\mathrm{Fe}^{3+}$. where surface oxygen species are partly consumed and regenerated during a continuous cycle. However. the iron atoms at the $\mathrm{B}$ site may be present in higher oxidation state as suggested by several investigators. ${ }^{2,9}$ If some $\mathrm{Fe}^{4+}$ ions exist in $\mathrm{LaFeO}_{3}$. some lanthamum ions could be removed from the lattice. based on the principle of controlled valency. The lanthamum oxide liberated from the $\mathrm{LaFeO}_{3}$ perovskite structure may change the catalytic properties of the perovskite catalyst. In the previous paper. ${ }^{1(1} \mathrm{LaFeO}_{3}$ and $\mathrm{LaCoO}_{3}$ prepared by the citrate sol-gel method revealed some activities in the oxidative coupling of methane above $650{ }^{\circ} \mathrm{C}$ and the activities were suggested to be attributable to lanthanum oxide unincorporated into the perovskite lattice. $\mathrm{La}_{2} \mathrm{O}_{3}$ catalyst is strongly basic and efficiently generates methyl radicals in the oxidative coupling of methane. 11.12 If a small amount of lanthanum oxide is isolated from the $\mathrm{LaFeO}_{3}$ peror skite lattice due to the presence of some $\mathrm{Fe}^{4+}$ ions the perovskite cataly'st would produce some $\mathrm{C}_{2}$ hydrocarbons in the oxidative coupling of methane. The aim of this work is to find the lanthanum oxide liberated from the $\mathrm{LaFeO}_{3}$ perovskite structure and to investigate its catalytic behaviors in $\mathrm{CH}_{4} / \mathrm{O}_{2}$ reaction above $600^{\circ} \mathrm{C}$. To do this. $\mathrm{LaFeO}_{3}$ and $\mathrm{La}_{1} \mathrm{FeO}_{3}$ perovskite oxides were prepared by the citrate sol-gel method and were examined as cataly sts for methane oxidation at a $\mathrm{CH}_{4} / \mathrm{O}_{2}$ ratio of 5 in the temperature range of $600-800{ }^{\circ} \mathrm{C}$ at atmospheric pressure. They were characterized by BET surface area measurement. XRD. DSC. EDX, FT-IR. and XPS.

\section{Experimental}

$\mathrm{LaFeO}_{3}$ oxides with $\mathrm{La} / \mathrm{Fe}$ atomic ratios of 0.9 and $\mathrm{I}$ were prepared from lanthanum nitrate $\left(\mathrm{La}\left(\mathrm{NO}_{2}\right)_{2} \cdot 6 \mathrm{H}_{2} \mathrm{O}\right.$. Aldrich, $>99.99 \%$ ) and ferric nitrate $\left(\mathrm{Fe}\left(\mathrm{NO}_{3}\right)_{3} 9 \mathrm{H}_{2} \mathrm{O}\right.$. Aldrich $\left.>99.99 \%\right)$. Both the lanthanum nitrate and iron nitrate were weighed to obtain the desired atomic ratio of $\mathrm{La} / \mathrm{Fe}$, and were then dissolved in deionized water. The resulting solution was mixed with an aqueous solution of citric acid to have the same anount of equivalents. Water was evaporated from the mixed solution at $70^{\circ} \mathrm{C}$ under vacuum to produce a viscous gel. The viscous gel was incubated at $120^{\circ} \mathrm{C}$ overnight to produce a solid amorphous mixture. The resulting mixture was ground, heated to $400^{\circ} \mathrm{C}$ for $8 \mathrm{~h}$, further heated at $800^{\circ} \mathrm{C}$ for $3 \mathrm{~h}$. and then cooled to room temperature at a cooling rate of $60^{\circ} \mathrm{C} / \mathrm{h}$. The $\mathrm{La}_{2} \mathrm{O}_{3}$ santele was prepared by decomposition of lanthanum

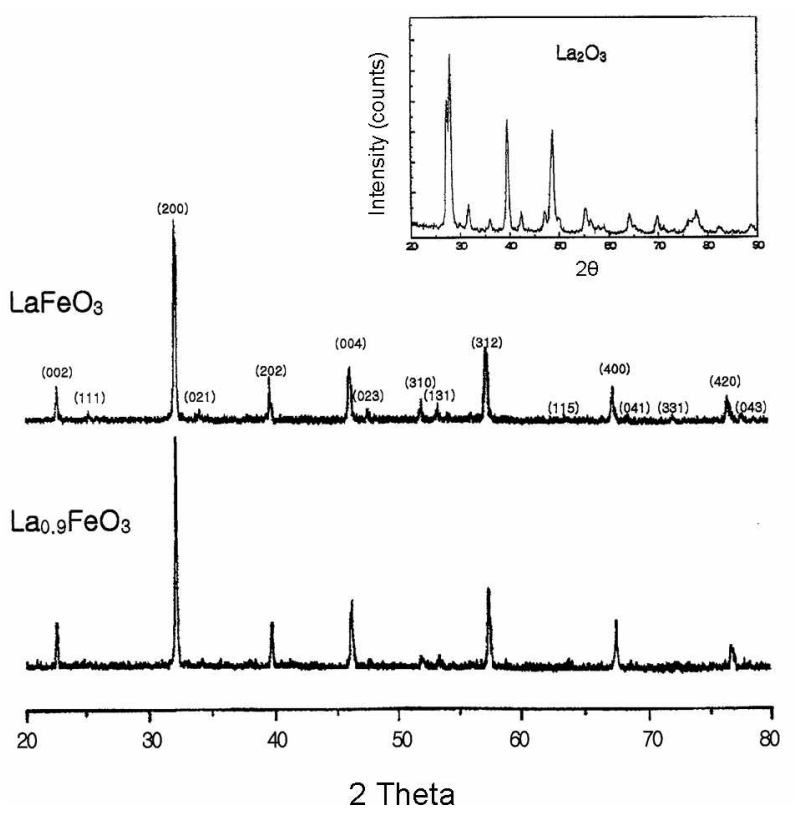

Figure 1. X-ray diftraction pattems of $\mathrm{LaFe}_{0} \mathrm{O}_{3}, \mathrm{LaFeO}_{3}$, and $\mathrm{La}_{2} \mathrm{O}_{3}$ samples. $\mathrm{La}_{2} \mathrm{O}_{3}$ (TCPDS no. 24-0554): LaFeO (TCPDS no. 15-0148). 
nitrate at $600{ }^{\circ} \mathrm{C}$ and calcination at $800^{\circ} \mathrm{C}$ in air. The BET surface areas of the samples were determined by $\mathrm{N}_{2}$ adsorption at the temperature of liquid nitrogen using a Micromeritics Accusorb 2100 sy stem and the values were $5.3 \mathrm{~m} / \mathrm{g}$ for the $\mathrm{LaFeO}_{3}$ and $4.2 \mathrm{~m}^{2} / \mathrm{g}$ for the $\mathrm{La}_{3} \mathrm{FeO}_{3}$ sample. X-ray powder diffraction (XRD) analysis was performed at room temperature by using a Philips PW-1710 diffractometer with Cu- $\mathrm{K}_{\triangleleft}$ radiation. A differential scanning calorimetry (DSC) analy sis was carried out by a Shimadzu DSC 60 equipment in flowing dried air $\left(10 \mathrm{~cm}^{3} / \mathrm{min}\right)$ at a heating rate of $10^{\circ} \mathrm{C} / \mathrm{min}$ up to $600^{\circ} \mathrm{C}$. The DSC curves of the $\mathrm{LaFeO}_{3}$ and $\mathrm{La}_{129} \mathrm{FeO}_{3}$ samples after exposure to wet air for $72 \mathrm{~h}$ at room temperature are presented in Figure 2, in which the $\mathrm{Laj}_{2.9} \mathrm{FeO}_{3}$ sample shows no endotherm peaks while the $\mathrm{LaFeO}_{3}$ sample shows a weak endotherm peak at $320^{\circ} \mathrm{C}$. To measure the bulk composition, EDX (energy dispersive X-ray) analy sis was performed for the catalysts by a Genesis EDX32. The concentrations of $\mathrm{La}$ and $\mathrm{Fe}$ were determined from their $\mathrm{K}$-lines and the $\mathrm{X}$-ray yields were adjusted by the $\mathrm{ZAF}$ correction. The $\mathrm{La} / \mathrm{Fe}$ atomic ratios determined by EDX were 1.05 for the $\mathrm{LaFeO}_{3}$ and 0.94 for the $\mathrm{La}_{3} \mathrm{FeO}_{3}$ sample, indicating that the values are close to the nominal ones. The surface composition and the valence state of each element were investigated by $\mathrm{X}$-ray photoelectron spectroscopy (XPS). XPS ansalysis of the catalysts was performed by a a Kratos Axis-Nova photoelectron spectrometer unit with a monochromated $\mathrm{Al} \mathrm{K}$ source. The base pressure in the analyzer chamber was less than $5.0 \times 10^{-9}$ Torr. The resulting binding energy values were corrected using the $\mathrm{C}$ ( Is) peak at $285.0 \mathrm{eV}$. The surface composition was calculated from the XPS peak area of each element by using the atomic sensitivity factors provided by the manufacturer. The surface $\mathrm{La} / \mathrm{Fe}$ ratios determined by XPS were 1.18 for the $\mathrm{LaFeO}_{3}$ and 1.06 for the $\mathrm{La}_{9} \mathrm{FeO}_{3}$. FT-IR spectra were obtained with a Fourier transfonm infrared (FT- $\mathbb{R})$ spectrometer (Perkin- Elmer Co.) at a resolution of $4.0 \mathrm{~cm}^{-1}$ and 32 scans. The sample disk for the FT-IR spectroscopic analy sis was made by compressing the mixture of sample $(10 \%)$ and $\mathrm{KBr}$. The FT-IR spectra of $\mathrm{LaFeO}_{3}, \mathrm{La}_{1}, \mathrm{FeO}_{3}$, and $\mathrm{La}_{2} \mathrm{O}_{3}$ samples after exposure to wet air for $72 \mathrm{~h}$ at room temperature. As presented in Figure 3. the $\mathrm{La}_{9} \mathrm{FeO}_{3}$ sample showed no

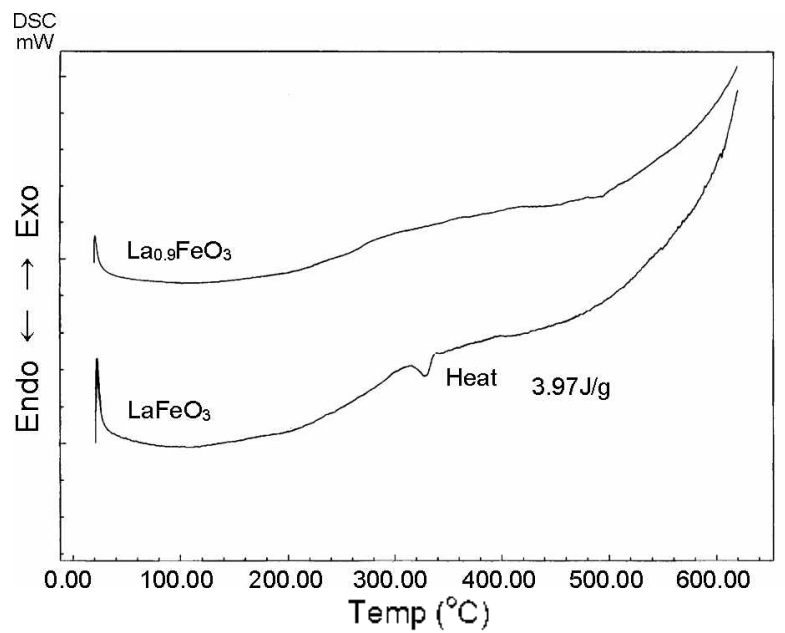

Figure 2. DSC curves of $\mathrm{La}_{4} \mathrm{FeO}_{3}$ and $\mathrm{LaFeO}_{3}$ samples after exposure to wet air. significant bands. while the $\mathrm{LaFeO}_{3}$ sample showed main bands or shoulders in the range of $2000.500 \mathrm{~cm}^{-1}$. The band at $1640 \mathrm{~cm}^{-1}$ is ascribed to an $\mathrm{O}-\mathrm{H}$ bending mode of hydroxide phase. the band at $640 \mathrm{~cm}^{-1}$ is characteristic of a bending $\mathrm{OH}$ vibration of the lanthanum hydroxide phase. and the bands at 1080 and $850 \mathrm{~cm}^{-1}$ are due to the carbonates. ${ }^{13-16}$

Catalytic reaction was carried out in a continuous flow tubular reactor which consisted of a $0.8-\mathrm{cm}-\mathrm{i}$.d. and 3 -cm-long quartz tube sealed to $0.4-\mathrm{cm}-\mathrm{i} . \mathrm{d}$. quartz tubes on two ends. The cataly st bed was placed in the $0.8 \mathrm{~cm}$-i.d. portion which was placed in a electrical furnace. To control the reaction temperature. a K-type thermocouple was placed in contact with the outside wall of the reactor next to the catalyst bed. The amount of catalyst was typically $50 \mathrm{mg}$. The catalyst loaded in the reactor was pre-treated in a flow of air $(20$ $\mathrm{cm}^{3} / \mathrm{min}$ ) at $800^{\circ} \mathrm{C}$ for $3 \mathrm{~h}$. The feed flow rate of the reaction nuxture at ambient condition was $\mathrm{CH}_{4} / \mathrm{O}_{2} / \mathrm{He}=10 / 2 / 28 \mathrm{~cm}^{3} /$ min and the flows of the gases were controlled by electronic mass flow controllers (Kofloc 3660). The purity of the gases was greater than $99.99 \%$ and the gases were dehydrated and purified with suitable filters. The gas products were analyzed by on-line gas chromatography (HP model 5890 plus) equipped with a thermal conductivity detector (TCD) and a flame ionization detector (FID). A cold trap was placed at the reactor exit to remove water vapor from the gaseous mixture. The conversion of methane was calculated from the anounts of products and the methane introduced into the feed stream. The selectivities were calculated on the basis of the conversion of methane to each product. The methane conversion and product selectivities were tỵ pically compared after l h time-on-stream.

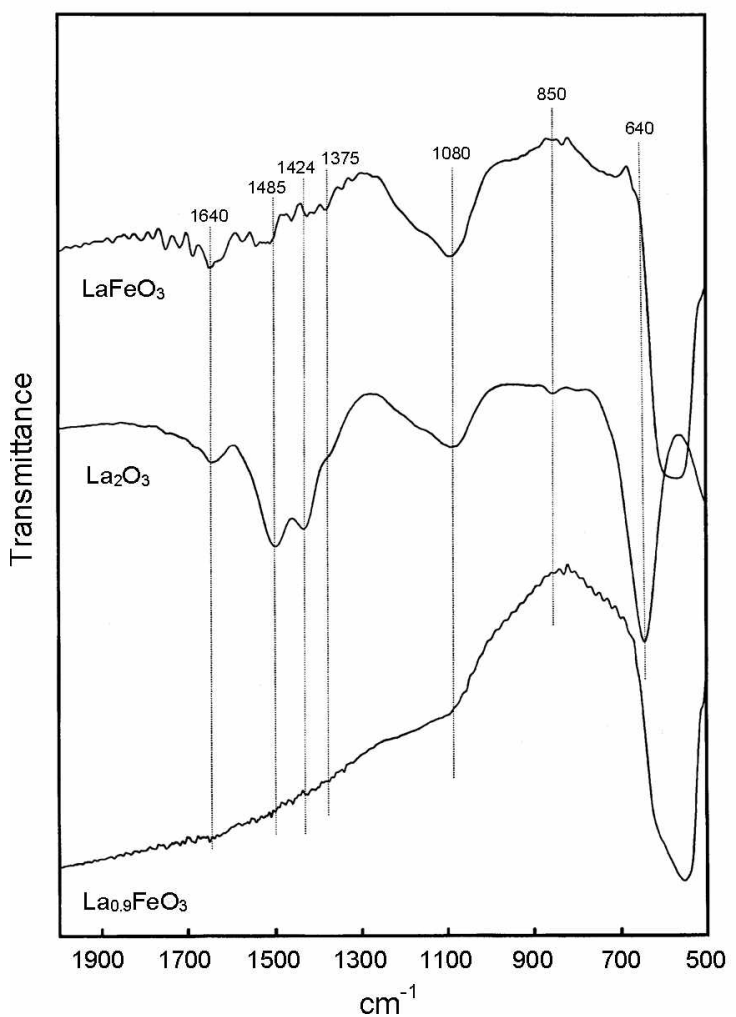

Figure 3. FT-IR spectra of $\mathrm{La}_{2} \mathrm{O}_{3}, \mathrm{La}_{0} \mathrm{FeO}_{3}$, and $\mathrm{LaFeO}$, samples after exposure to wet air. 
The blank tests perfonmed in a flow of the $\mathrm{CH}_{4} / \mathrm{O}_{2} / \mathrm{He}(=10 /$ $2 / 28 \mathrm{cc} / \mathrm{min}$ ) reaction mi.ture showed methane conversion of $0-2.6 \%$ to $C_{3}$ lydrocarbons in the temperature range of $600-800^{\circ} \mathrm{C}$. The details of catalytic experiment were described in the previous paper. ${ }^{17.1 \mathrm{z}}$

\section{Results and Discussion}

Figure 1 shows the $\mathrm{X}$-ray powder diffraction patterns of the $\mathrm{LaFeO}_{3}$ and $\mathrm{La}_{9} \mathrm{FeO}_{3}$ samples. which indicates the formation of monophase perovskite oxides having orthorhombic stnicture. In this work, the surface $\mathrm{La} / \mathrm{Fe}$ atomic ratio. 1.18, determined by XPS for the $\mathrm{LaFeO}_{3}$ sample was higher than the nominal one, indicating that lanthanum is more rich on the surface than in the bulk. To verify the presence of lanthamum oxide liberated from the perovskite lattice. DSC analysis was performed for the sample after exposure to wet air and the results are shown in Figure 2. Because lanthanum oxide is easily converted to the hydroxide form even at room temperature in air. the lanthanum oxide aged in air reveals an endotherm peak due to the dehydration. ${ }^{13} \mathrm{~A}$ weak endotherm peak observed at $320^{\circ} \mathrm{C}$ is attributable to the removal of hydroxyl groups from lanthanum hydroxide formed by hydration of lanthanum oxide in wet air. The result implies that lanthanum oxide in a small amount exists in the oxide. Figure 3 compares the FT-IR spectra of $\mathrm{LaFeO}_{3} \mathrm{La}_{9} \mathrm{FeO}_{3}$. and $\mathrm{La}_{2} \mathrm{O}_{3}$ samples after exposure to wet air at room temperature. The FT-IR spectrum of $\mathrm{LaFeO}_{3}$ sample displays absorption bands at $1640 \mathrm{~cm}^{-1}$ due to an $\mathrm{O}-\mathrm{H}$ bending mode of adsorbed $\mathrm{H}_{2} \mathrm{O}$ and $640 \mathrm{~cm}^{-1}$ due to a bending $\mathrm{OH}$ vibration of the lanthanum hyddroxide phase. ${ }^{13-16}$ The result supports that lanthanum oxide exists in the $\mathrm{LaFeO}_{2}$ sample. The isolated lanthanum oxide which was not detected by $\mathrm{XRD}$ presumably exists as nanoparticles or amorphous in the perovskite. The liberation of lanthanum oxide from the $\mathrm{LaFeO}_{2}$ perovskite lattice is considered to be due to the unusual oxidation state of iron. $\mathrm{Fe}^{4+}$. in the oxide. When a part of $\mathrm{Fe}^{3+}$ ions is oxidized to $\mathrm{Fe}^{4+}$ ions, a part of lanthanum ions would be removed from the peropvskite lattice based on the principle of controlled valency. According to Ciambelli et al ${ }^{19}$ and Barbero et al. ${ }^{20}$ the $\mathrm{Fe}^{4-}$ content detennined from the TPR data of $\mathrm{LaFeO}_{3}$ perovskite is $2.8 \%$ after calcination at $600{ }^{\circ} \mathrm{C}$ and $1.3 \%$ after calcination at $800^{\circ} \mathrm{C}$. indicating that the $\mathrm{Fe}^{+-}$content decreases with increasing the calcination temperature. Their results are agreeable to the present results showing the presence of isolated lanthanum oxide in the $\mathrm{LaFeO}_{3}$ sample calcined at $800^{\circ} \mathrm{C}$

Figure + reveals the XPS spectra of $O(1 \mathrm{~s}), \mathrm{La}(3 \mathrm{~d})$. and $\mathrm{Fe}(2 \mathrm{p})$. The binding energies of $\mathrm{La} 3 \mathrm{~d}_{5: 2 .} 833.5 \mathrm{eV}$ for the $\mathrm{LaFeO}_{3}$ sample and $833.8 \mathrm{eV}$ for the $\mathrm{La}_{3} \mathrm{FeO}_{3}$ sample, correspond to $\mathrm{La}^{3-}$ ions in oxide form and the binding energy of $\mathrm{Fe}$ $2 \mathrm{p}_{3: 5}, 710.2 \mathrm{eV}$ for both the samples. corresponds to $\mathrm{Fe}^{3-}$ ions in oxide form. ${ }^{9.21}$ We could not distinguish $\mathrm{Fe}^{3-}$ and $\mathrm{Fe}^{4+}$ from the $\mathrm{Fe}(2 \mathrm{p})$ XPS signal. The O(ls) XPS signal of $\mathrm{La}_{1.9} \mathrm{FeO}_{3}$ sanple was divided into two peaks at 529.9 and $532.1 \mathrm{eV}$, while that of $\mathrm{LaFeO}_{3}$ sample was divided into three peaks at 529.4, 531.9. and $534.4 \mathrm{eV}$. The $\mathrm{O}(\mathrm{ls})$ binding energies at $529.9 \mathrm{eV}$ and $529.4 \mathrm{eV}$ are ascribed to lattice oxygen species. The binding energies at 532.1 and $531.9 \mathrm{eV}$ can be assigned to chemisorbed oxygen species $\left(\mathrm{O}^{-}\right)$or $\mathrm{OH}^{-}$species because the $\mathrm{O}(\mathrm{ls})$ binding energy of $\mathrm{O}^{-}$or $\mathrm{OH}^{-}$ion is generally higher by

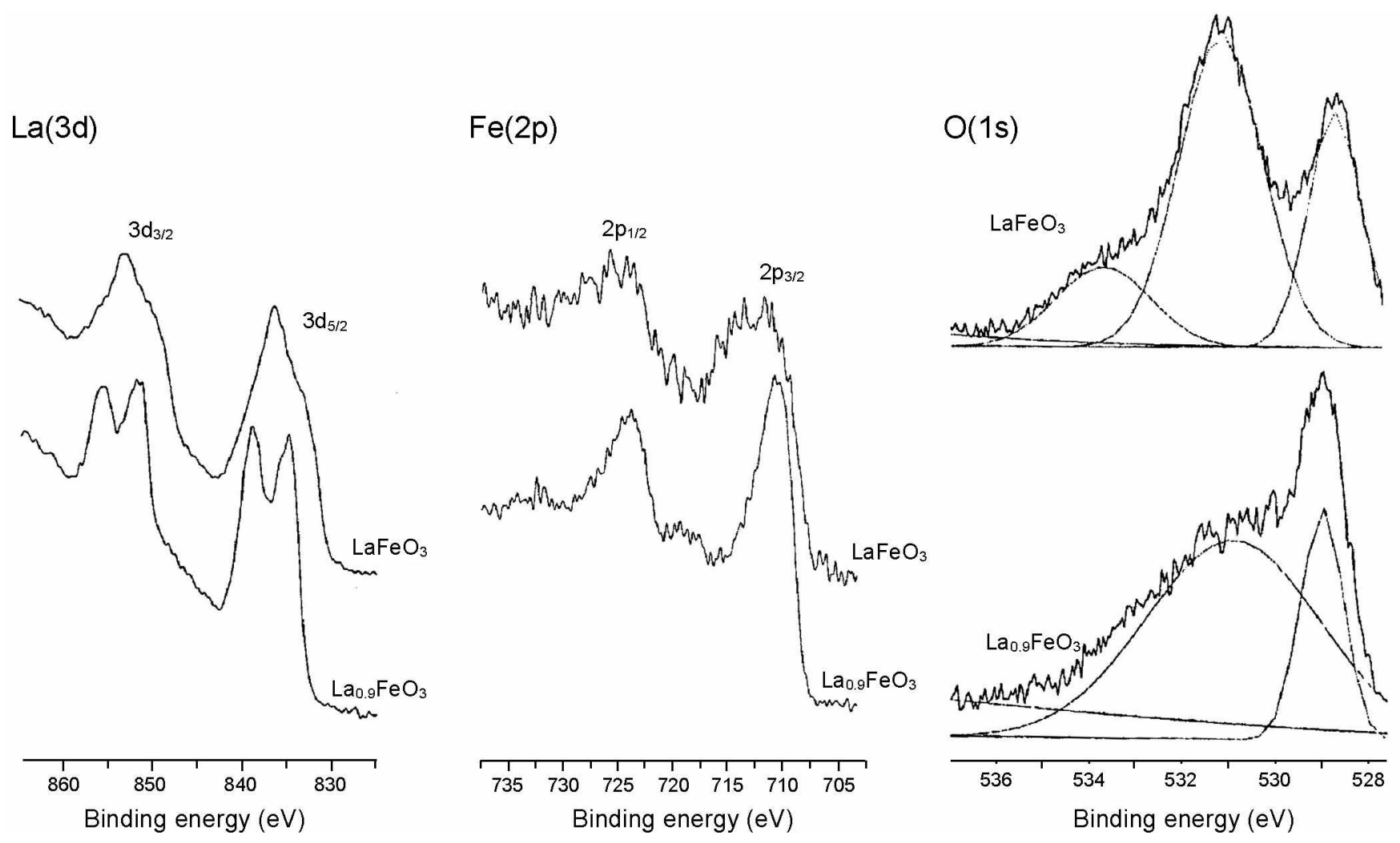

Figure 4. $\mathrm{La}(3 \mathrm{~d}), \mathrm{Fe}(2 \mathrm{p})$, and $\mathrm{O}(1 \mathrm{~s}) \mathrm{XPS}$ spectra of $\mathrm{La}, \mathrm{FeO}$, and $\mathrm{LaFeO}_{3}$ samples. 


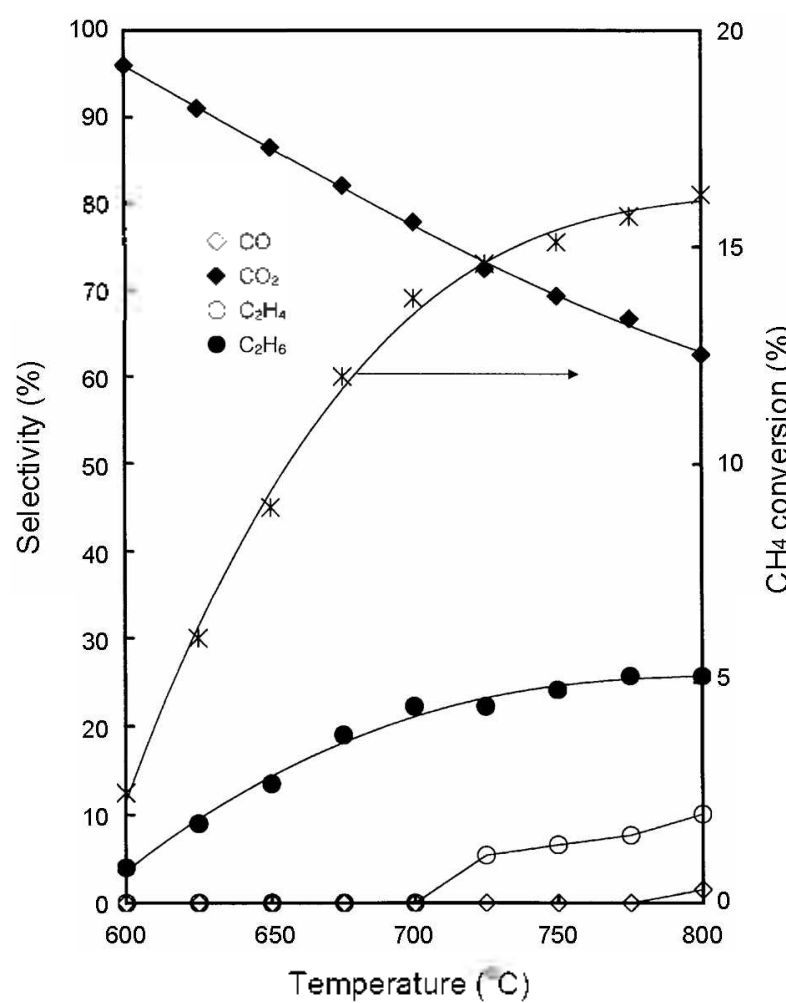

Figure 5. Selectivities and methane conversion of LaFeOs catalyst for methane oxidation at a $\mathrm{CH}_{4} / \mathrm{O}_{2}$ ratio of 5 in the temperature range of $600-800^{\circ} \mathrm{C}$.

a $2.1-2.5 \mathrm{eV}$ than that of lattice oxygen..$^{-2}$ The binding energy at $534.4 \mathrm{eV}$ observed for the $\mathrm{LaFeO}_{3}$ sample is attributed to the adsorbed water species." ${ }^{2-}$ Because lanthanum oxide is easily hygroscopic when it is exposed to air the higher $\mathrm{O}(1 \mathrm{~s})$ binding energy $(534.4 \mathrm{eV})$ is considered to be due to water molecule associated with the surface lanthanum oxide

In the $\mathrm{CH}_{4} / \mathrm{O}_{2}$ reaction. the $\mathrm{LaFeO}_{3}$ catalyst produced $\mathrm{CO}_{3}$. $\mathrm{C}_{2} \mathrm{H}_{4}$. and $\mathrm{C}_{2} \mathrm{H}_{6}$ as major products in the temperature range of $600-800^{\circ} \mathrm{C}$. Figure 5 shows methane conversion and product selectivities of the $\mathrm{LaFeO}_{3}$ catalyst. in which the $\mathrm{C}_{2}$ yield at $800{ }^{\circ} \mathrm{C}$ is $5.8 \%$ in a selectivity of $35.8 \%$. On the other hand. the $\mathrm{La}_{9} \mathrm{FeO}_{3}$ catalyst showed total oxidation activity for the reaction as shown in Figure 6 . The $\mathrm{La}_{9} \mathrm{FeO}_{3}$ cataly st produced $\mathrm{C}_{\geq}$hydrocarbons in a selectivity below $9.5 \%$ in the temperature range of $725-800^{\circ} \mathrm{C}$ and the $\mathrm{C}_{2}$ yield at $800^{\circ} \mathrm{C}$ was merely $1.2 \%$. In the previous paper. we reported that the $\mathrm{CH}_{4} / \mathrm{O}_{2}$ reaction in a quartz flow reactor produces $\mathrm{C}_{2}$ hydrocarbons below $800^{\circ} \mathrm{C}$ in the absence of catalyst. ${ }^{17}$ In this work. the blank test showed a $\mathrm{C}_{2}$ yield of $2.6 \%$ at $800{ }^{\circ} \mathrm{C}$ and the value is higher than $1.2 \%$ of the $\mathrm{La}_{3} \mathrm{FeO}_{3}$ cataly st. suggesting the $\mathrm{C}_{2}$ production catalyzed by the $\mathrm{La}_{0.9} \mathrm{FeO}_{3}$ to be negligible. Because the specific surface areas of the $\mathrm{LaFeO}_{3}$ and $\mathrm{La}_{4} \mathrm{FeO}_{3}$ samples. 5.3 and $4.2 \mathrm{~m}^{2} / \mathrm{g}$. are very low and do not differ significantly, the differences in cataly tic properties of both the catalysts is inferred to be closely related to their surface structures.

Many investigations for the oxidative coupling of methane over metal oxide catalyst have shown that less electrophilic oxygen species adsorbed on oxygen vacancy sites effectively generate methyll radicals which are coupled to form ethane in

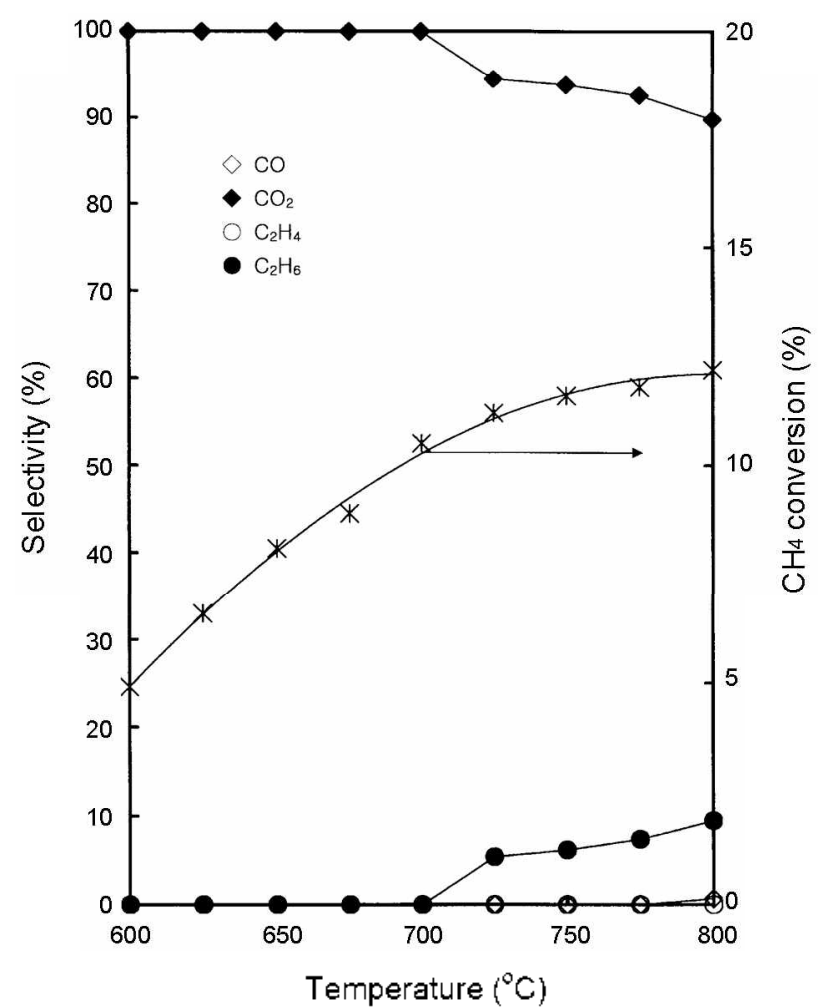

Figure 6. Selectivities and methane conversion of $\mathrm{Lak}(\mathrm{FeO}, \mathrm{catalyst}$ for methane oxidation at a $\mathrm{CH}_{4} / \mathrm{O}_{2}$ ratio of 5 in the temperature range of $600-800^{\circ} \mathrm{C}$.

the gas phase. ${ }^{22}$ The present $\mathrm{La}_{0} \mathrm{FeO}_{3}$ cataly st was found to be a single phase perovskite having orthorhombic structure by $\mathrm{XRD}$. The non-stoichiometric $\mathrm{La}, \mathrm{FeO}_{3}$ oxide can be written as $\mathrm{La}_{0}, \mathrm{FeO}_{2}$ s. If some $\mathrm{Fe}^{4-}$ ions are present in the oxide the

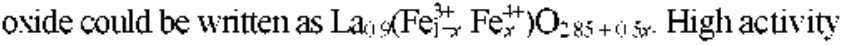
of the $\mathrm{La}_{1} \mathrm{FeO}_{\mathrm{s}}$ catalyst for total oxidation of methane is believed to be closely related to oxygen vacancy as suggested by other investigators. ${ }^{3,23}$ Because the $\mathrm{La}_{0} \mathrm{FeO}_{3}$ catalyst negligibly produced $C_{2}$ hydrocarbons in this reaction oxygen vacancy seems to be not directly related to the formation of $C_{2}$ hydrocarbons. As mentioned above. the $\mathrm{LaFeO}_{3}$ sample is considered to be a mixed phase of isolated lanthanum oxide and lanthanum-deficient $\mathrm{LaFeO}_{3}$ perovskite oxide. It can be represented as $\frac{x}{6} \mathrm{La}_{2} \mathrm{O}_{3} / \mathrm{La}_{1-\frac{1}{3}}\left(\mathrm{Fe}_{1-x}^{3+} \mathrm{Fe}_{x}^{++}\right) \mathrm{O}_{3}$. The isolated lanthanum oxide may be related to the nature and reactivity of the perovskite surface. Lanthanum oxide is known to be an active and selective catalyst for the oxidative coupling of methane, which enables us to consider that the $C_{2}$ production over the $\mathrm{LaFeO}_{3}$ catalyst is attributed to the surface lanthanum oxide. In the oxidative coupling of methane over metal oxide catalyst, $\mathrm{CO}$ is generally produced as a major product. However, the present $\mathrm{LaFeO}_{3}$ cataly st scarcely produced $\mathrm{CO}$ in the reaction as shown in Figure 6, which implies that $\mathrm{CO}$ can be further oxidized to $\mathrm{CO}_{2}$ on the perovskite containing oxygen vacancies which act as active site for total oxidation of methane.

Consequently. when the $\mathrm{LaFeO}_{\text {s }}$ perovskite is prepared by the citrate sol-gel method and calcined at $800{ }^{\circ} \mathrm{C}$. lanthanum deficiencies are created in the $\mathrm{LaFeO}_{s}$ perovskite owing to the presence of $\mathrm{Fe}^{+-}$ion in the perovskite. resulting in the libera- 
tion of lanthanum oxide from the perovskite lattice. The $\mathrm{LaFeO}_{3}$ perovskite catalyst shows total oxidation activity in the $\mathrm{CH}_{4} /$ $\mathrm{O}_{2}$ reaction below $700^{\circ} \mathrm{C}$. but above $700^{\circ} \mathrm{C}$ it shows some activity for the oxidative coupling of methane. The surface lanthanum oxide liberated from the perovskite structure is responsible for the modification of catalytic properties of $\mathrm{LaFeO}_{3}$

Acknow ledgments. This work was supported by research funds from Yonsei University in 2008 and the Korea Science and Foundation through the Pioneer Converging Technology Program (No. M10711160001-08M1116-00110). Y.-G. Cho and $\mathrm{K} . \mathrm{H}$. Choi thank the fellowship of the BK2I program from the Ministry of Education and Human Resources Development.

\section{References}

1. Seiyana, T. In Propenties and Applications of Perovshite-tope Oxides: Tejuca, L. G.; Fierro, J. L. G., Eds.; Marcel Dekker Inc.: New York, 1993; p 215.

2. O'Connell, M.; Norman1, A. K.; Hüttennanu, C. F.: Morris, M. A. Catalysis Todoy 1999, 47, 123 .

3. Spinicci, R.; Tofanari, A.; Delmastro, A.; Mazza, D.; Ronchetti, S. Mat. Chem. Phys. 2002, 76, 20.

4. Merino, N. A.: Barbero, B. P.; Grange, P.; Cadus, L. E. J. Catal. $2005,231,232$.

5. Kucharczy, B.: Tylus, W. Appl Catal. A 2008, 335, 28.

6. Spinicci, R: Martini, P.; DeRossi, S.; Faticanti, M: Porta, P. J. Afole. Catal. 4 2001, 176, 253.
7. Delmastro, A.; Mazza, D.; Ronchetti, S.; Vallino, M.; Spinicci, R; Brovetto, P.; Salis, M. .Hot. Sci. Eng. 2001, B79, 140.

8. Zhong, Z; Chen, K.; Ji, Y: Yan, Q. Appl. Catal A 1997, 156, 290.

9. Rida, K.; Benabbas, A.; Bouremmad, F.: Pena, M. A.: Sastre, E.: Martinez-Arias, A .Appl Catal . 1 2007, 327, 173.

10. Lee, M.-J.: Jun, J.-H.; Jung, J.-S.: Kim, Y.-R.: Lee, S.-H. Buhl. Korean Chem. Soc. 2005, 26, 1591.

11. Campbell, K. D.: Zhong. H.; Lunsford, J. H. J. Phus. Chem. 1988.92 .750 .

12. Lacombe, S.: Geanter, C.; Mirodatos, C. J. Catal 1994, $151,439$.

13. Bemal, S.; Botana, F. I.; Garcia, R.: Rodriguez-Izquierdo, I. M. Reactivity of Solids $1987,4,23$.

14. Van, T.; Le Che, M.; Tatibouët, J. M:; Kermarec, M. J. Catal. $1993,1+2,18$.

15. Colon, G.; Navio, J. A.; Monaci, R:; Ferino, I. Phys. Chem. Chent. Phys. 2000, 2, 4453

16. Valange, S.; Beauchaud, A.; Barrault, T.; Gabelica, Z.; Daturi, M.; Can, F. J. Catal. 2007, 251, 113

17. Cho, Y.-G.; Choi, K.-H.; Kim, Y.-R.; Lee, S.-H. Bull Konem Chem. Soc. 2008, 29, 1609

18. An, B.-I.; Ryul, K.-H.; Kim, Y.-R.: Lee, S.-H. Bull Korean Chem. Soc. 2007, 28, 1049 .

19. Ciambelli, P.; Cimino, S.; De Rossi, S.: Lis, L.; Minelli, G.; Porta, P.; Russo, G. Appl Catal. B 2001, 29, 239.

20. Barbero, B.; Gamboa, J. A.: Cadus, L. E. Appl. Catal B 2006, 65,21 .

21. In Handbook of $\mathrm{Aray}$ Photoelectron Spectroscopv, Wagner, C. D; Riggs, W. M.; Davis, L. E:; Moulder, J. F.; Muilenberg, G. E., Eds.; Perkin-Elmer Co.: 1979

22. Michevicius, S.; Grebinskij, S.; Bondarenka, V.; Vengalis, B.; Sliuziene, K.; Orlowski, B. A.; Osinuiy, V; Drube, W. J. Allow: Comp. 2006, 423,107

23. Lunsford, J. H. Angew. Chent 1995, 34, 970. 